\title{
hermeneutical injustice and outsourced domestic girl-child labour
}

\author{
dominic effiong abakedi ${ }^{1}$ \\ university of calabar, nigeria \\ orcid id: http:/ / orcid.org/0000-0002-8551-577X \\ emmanuel kelechi iwuagwu ${ }^{2}$ \\ university of calabar, nigeria \\ orcid id: https:/ / orcid.org/0000-0002-1304-1966 \\ mary julius egbai ${ }^{3}$ \\ university of calabar, nigeria \\ orcid id: https://orcid.org/0000-0002-7311-2076
}

\begin{abstract}
We observed that despite international declarations on child-rights, outsourced domestic girl-child labour still persists. Raising the question whether outsourced domestic girl-child labour constitutes hermeneutical injustice, we respond affirmatively. Relying on two indigenous victimology-narratives that are newspaper reports, we expose some of the horrors that the victims of outsourced domestic girl-child labour suffer. Comparing these reports with other victimology-narratives of hermeneutical injustice as reported by Miranda Fricker and Hilkje Hänel, we argue that the victims of outsourced domestic girlchild labour suffer a hermeneutical gap and hermeneutical interference; and that the perpetuators of this practice, help to foster what we call 'hermeneutical obstruction'. We recommend different counteracting measures such as: a radical feminization of educational curricula, which will allow for the introduction of the relevant hermeneutical resources that female children need in making sense of their experiences, into the classrooms and other places of learning; establishing feminist liberation agencies in all schools, religious institutions and hospitals, as ways of increasing the level of awareness about the rights of the girl-child in children and adults; feminizing legislation and legislative processes, to allow for the enactment of laws to protect the rights of the girl-child; and campaigning for a more rigorous enforcement of child-rights laws.
\end{abstract}

keywords: hermeneutical injustice; child-labour; child-rights; girl-child.

\section{injustiça hermenêutica e terceirização da mão-de-obra infanto-feminina doméstica}

\section{resumo}

Observamos que, apesar das declarações internacionais sobre os direitos das crianças, ainda persiste a mão de obra infantil feminina doméstica terceirizada. Levantando a questão se o trabalho terceirizado de meninas e adolescentes domésticas constitui uma injustiça hermenêutica, respondemos afirmativamente. Confiando em duas narrativas de vítimas indígenas - que são reportagens de jornais - expomos alguns dos horrores que sofrem as meninas e meninos vítimas do trabalho doméstico terceirizado. Comparando essas reportagens com outras narrativas de vítimas de injustiça hermenêutica, como relatado por Miranda Fricker e Hilkje Hänel, argumentamos que as vítimas do trabalho infantil doméstico terceirizado sofrem uma lacuna e interferência hermenêuticas; e que os perpetuadores dessa prática, ajudam a fomentar o que chamamos de "obstrução

\footnotetext{
${ }^{1}$ E-mail: dominicabakedi@gmail.com

2 E-mail: emmanueliwuagwu@unical.edu.ng

${ }_{3}^{3}$ E-mail: maryegbai@unical.edu.ng
} 
hermenêutica". Recomendamos diferentes medidas de combate como, por exemplo uma feminização radical dos currículos educacionais, que permitirá a introdução dos recursos hermenêuticos relevantes que as meninas necessitam para dar sentido às suas experiências, nas salas de aula e outros lugares de aprendizagem; o estabelecimento de agências feministas de libertação em todas as escolas, instituições religiosas e hospitais, como formas de aumentar o nível de conscientização sobre os direitos das crianças e adultos; a feminização da legislação e dos processos legislativos, para permitir a promulgação de leis para proteger os direitos das crianças femininas; e a campanha por uma aplicação mais rigorosa das leis sobre os direitos das crianças.

palavras-chave: injustiça hermenêutica; trabalho infantil; direitos da criança; menina

\section{injusticia hermenéutica y subcontratación de trabajo doméstico de niñas}

\section{resumen}

Observamos que, a pesar de las declaraciones internacionales sobre los derechos de los niños y niñas, todavía persiste el trabajo infantil doméstico subcontratado. Planteando la cuestión de si el trabajo doméstico subcontratado de niñas constituye una injusticia hermenéutica, respondemos afirmativamente. Basándonos en dos relatos de víctimas indígenas que son informes periodísticos, exponemos algunos de los horrores que sufren las víctimas del trabajo doméstico de las niñas subcontratado. Comparando estos informes con otros relatos de víctimas de injusticia hermenéutica como los de Miranda Fricker y Hilkje Hänel, argumentamos que las víctimas del trabajo doméstico subcontratado de niñas sufren una brecha hermenéutica y una interferencia hermenéutica; y que los perpetuadores de esta práctica ayudan a fomentar lo que llamamos "obstrucción hermenéutica". Recomendamos diferentes medidas para contrarrestarla, tales como: una feminización radical de los programas educativos, que permita introducir en las aulas y otros lugares de aprendizaje los recursos hermenéuticos pertinentes que las niñas necesitan para dar sentido a sus experiencias; el establecimiento de organismos de liberación feminista en todas las escuelas, instituciones religiosas y hospitales, como formas de aumentar el nivel de conciencia sobre los derechos de la infancia en niñas, niños y adultos; la feminización de la legislación y los procesos legislativos, para permitir la promulgación de leyes que protejan los derechos de las niñas; y la realización de campañas para lograr una aplicación más rigurosa de las leyes sobre los derechos de los niños y niñas.

palabras clave: injusticia hermenéutica; trabajo infantil; derechos del niño; niña. 
hermeneutical injustice and outsourced domestic girl-child labour

\section{introduction}

The concept of hermeneutical injustice (HI from now onwards), first coined by Fricker (2007), has gained wide reception-different authors have used it to describe different contexts, where one's social experiences are obscured from collective understanding (cf. Dotson 2011; Hull 2017; Kid, Median \& Pohlhaus 2017; Goetze 2018; Elzinga 2018; Maitra 2018; Podolsky 2018). Some have seen the need to modify Fricker's model of HI to accommodate new socio-cultural experiences (cf. Crerar 2016; Podolsky 2018; Goetze 2018). Others have presented HI as a problem of recognition or misrecognition (cf. Congdon 2017; Giladi 2018, Hänel 2020). All these investigations are aimed at resisting and combating $\mathrm{HI}$ as a form of epistemic injustice. However, the victimology-narratives discussed in the foregoing articles do not include the plight of female children who do outsourced domestic work.

Many authors have written on the injustices that women who do outsourced domestic work suffer (cf. Moors 2003; Begum 2016), while others have attempted to show that outsourced domestic labour is a form of HI. ${ }^{4}$ Many people have witnessed how female children suffer the injustices associated with outsourced domestic labour, especially in West Africa, but few rise up to combat it. Besides, feminist scholarship on how outsourced girl-child labour in Africa constitutes $\mathrm{HI}$ is lacking. ${ }^{5}$ This implies that the phenomenon of 'Outsourced Domestic Girl-child Labour' (ODGL from now onwards), as a form of HI, has been under-discussed. ${ }^{6}$ Inspired by this, and by the different investigations that are attempts to expose and combat different forms of $\mathrm{HI}$, we will try to show that ODGL is a form of $\mathrm{HI}$, and in that regard, should be resisted and combated. We will also make some recommendations.

\footnotetext{
${ }^{4}$ We acknowledge the contribution of Shahvisi (forthcoming), which is a recent attempt to show how outsourced domestic work done by women is a form of $\mathrm{HI}$.

${ }^{5}$ During sensitization campaigns in our local academic community, many female students often expressed disappointment that scholarship in feminist philosophy, especially in journals indexed in Clarivate analytics, hardly address the plight of female students in Africa.

${ }^{6}$ Baumtrog notes that Fricker's discussion about $\mathrm{HI}$ does not seem to include the experiences of children (2018). However, we acknowledge Baumtrog's attempt to show that child-labour constitutes HI (cf. Baumtrog 2018, 298301). Elicor (2020) has argued that epistemic injustice as identity prejudice arises circumstantially and substantively in P4WC scholarship and practice
} 
Using the method of critical exposition and comparative analysis, in the second section we will discuss what $\mathrm{HI}$ is. In the third section, we will explain how ODGL is a form of HI. In doing so, we will adopt two victimology-narratives explicating some horrible experiences associated with ODGL, and by comparing them with the victimology-narrative of Fricker, we will argue that ODGL explicates a hermeneutical gap and hermeneutical interference. We will also introduce a new concept, 'hermeneutical obstruction', to explain situations where one conceals knowledge from those who are marginalized, because of one's refusal to part with a given prejudiced identity or misrecognition. In the fourth section, we will discuss the harm associated with ODGL as a form of HI. In the fifth section, we make some recommendations for combating ODGL as a form of HI. We conclude that reorienting society through a revised educational curricula, feminized legislation, a rigorous enforcement of child-rights laws is needed.

\section{hermeneutical injustice}

HI, like 'testimonial injustice', is a form of discriminatory epistemic injustice (Agra 2020,30). Testimonial injustice is a harm done to someone in their capacity as bearers and transmitters of knowledge (Agra 2020,31). It happens when the veracity of a testimony is unjustly evaluated based on a prejudiced way of perceiving the speaker (Agra 2020,31). This is what Fricker calls "identity-prejudicial credibility deficit" (Fricker 2007, 28).

$\mathrm{HI}$ is an epistemic wrong done to someone in their capacity as a knower, but facilitated by some structural identity prejudices, which obscures people's social experiences from being collectively understood (Fricker 2017, 155). It occurs when there is a deficiency in our shared tools of social interpretation, which is the collective hermeneutical resource, and so marginalized social groups are at a disadvantage in making sense of their distinctive and important experiences (Goetze 2018). In other words, HI occurs when there is a gap in the interpretive resources available to members of a society due to the marginalization of members of a social group, from sense making practices (Elzinga 2018). 
Fricker avers that identity prejudices can lead to HI. Her victimologynarratives of the respective experiences of Wendy Sanford and Carmita Wood (Fricker 2007, 149-151), are relevant to this paper in two directions. First, in showing that the feminist method of victimology is foundational to feminist discourses on HI, from the outset of Fricker's maiden work in 2007. Secondly, they serve as victimology-models for comparative analyses. According to Fricker's narrative, Wendy Sanford, an adult female, kept blaming herself for being a bad mother until she was fortunate to learn the concept of 'post-partum depression' during a feminist consciousness-raising meeting, which a friend led her to attend (Fricker 2007). This concept helped her to make sense of her experiences, as she came to understand that what she was experiencing was not as a result of personal deficiency, but the combination of post-partum depression and isolation. The former is a psychological reality, and the latter is a social reality (Fricker 2007). Fricker's second victimologynarrative is that of Carmita Wood, a black woman that had to quit her job to avoid the aggressive advances of one of her superiors, because she always felt ashamed and embarrassed. But on quitting her job, she was unjustly denied unemployment benefits. Fricker's argument, using this latter victimology-narrative, is that Wood did not possess the concept of 'sexual harassment', which is a relevant feminist concept that would have helped her in making sense of what she was facing, and which would have helped her to denounce the vicious behaviour of her superior, and perhaps save her job.

Hilkje Hänel uses the experiences of Anna, a female undergraduate student of philosophy, to illustrate that hermeneutical injustice can be understood as a problem of misrecognition (Hänel 2020, 338-343). Reading through Hänel's work, one can say that her illustration seems to corroborate an earlier thesis given by Charlie Crerar (2016), namely, that it is possible that one may be unable to interpret one's social experiences, despite having relevant concepts at one's disposal, due to societal taboos that stand as hindrances. This is what Hänel $(2020,339)$ calls 'hermeneutical interference'. Thus, one can identify in recent literature that some authors present $\mathrm{HI}$ as what results from hermeneutical gap, that is, a situation where one lacks interpretive resources to make sense of an experience. To lack 
interpretive resources to make sense of an experience, is to lack conceptual skills or know-how (Elzinga 2018).

Some authors have argued that Fricker's account is not broad enough to accommodate all possible contexts of social experiences, and, as such, the meaning of HI should not be restricted to the notion of a hermeneutical gap (cf. Podolsky 2018; Goetze 2018). For instance, some critiques have argued that Fricker's account ignores the phenomenon of hermeneutical dissent, a situation where marginalized groups create their own interpretive tools away from the collective hermeneutical resource (cf. Mason 2011, Dotson 2012; Medina 2013). Fricker has responded that her original account of HI, accommodates hermeneutical dissent (Fricker 2016, 167); that the collective hermeneutical resource should be seen as a collection of concepts that are held in common (Fricker 2016, 163). However, it appears that her response to her critics has not deterred further developments on the theory of hermeneutical dissent. For example, Trystan Goetze defended the thesis of hermeneutical dissent by averring that members of the LBGTQ+ communities have created their own concepts (such as agender) away from the collective hermeneutical resource to make sense of their social experiences (Goetze 2018), ${ }^{7}$ Goetze argues that hermeneutical dissent is also a form of HI (Goetze 2018).

Recent works on HI are not restricted to the defense or critique of either the hermeneutical gap, hermeneutical interference or hermeneutical dissent. Nevertheless, on the question of how they are relevant to this paper, we would say that they serve as ideological frameworks for investigating the social phenomenon of ODGL. In the following section, we expose some practices associated with ODGL, as reported in one of the daily media outlets of a country in West Africa. There may be numerous accounts of the horrors of ODGL in many other documents; however, the account of Evelyn Usman and Charly Agwam, whom we will turn to next, suffices, for the purpose of this paper, to expose some of the horrors that the girlchild faces as an outsourced domestic worker.

\section{outsourced domestic girl-child labour as hermeneutical injustice}

\footnotetext{
${ }^{7}$ For more on the critique from LBGTQ+, we refer the reader to Mason 2011; Dotson 2012; Medina 2013.
} 
ODGL is here defined as the situation where girls, who are less than eighteen years of age, are made to leave the custody of their biological parents or guardians, to live with other people (such as another family), but end up as unpaid domestic workers that are subjected to different kinds of exploitation and abuse. New estimates given by the International Labour Organization, on children engaged in child labour, forced labour and labour resulting from human trafficking in SubSaharan Africa, indicate that the phenomenon has not ceased (ILO 2020). The problem of child-labour is widespread, so much so that about twenty-five percent of the population of children in the world are engaged in child labour, as shopkeepers, street vendors and domestic workers (Tundui \& Tundui 2018). The major reason for child-labour is household income poverty (Richter \& de Coninck 2015). The experiences of children who are engaged in child labour include different manners of verbal and physical abuse such as: starvation, poor wages or no wages, assault, sexual molestation, rape, neglect. In many parts of the world, child labour is forced on children and mostly without pay, and also happens within familial settings (Usman 2020). Children from poor or low-income families are the major victims, but the girl-child is the most affected. But one may not understand the experiences of cruelty associated with ODGL if one does not have access to testimonies. The feminist approach of victimology, therefore, is a good way to render some of those experiences intelligible. In the following paragraphs, we give two victimology-narratives - both are newspaper reports. The first is a report of what some female children engaged in ODGL go through, and the second, on teenage marriage that results in what is conventionally described as homicide. We intend to use these testimonies to argue that ODGL, to some extent, constitutes HI.

Usman, in describing the prejudiced identity of girls who are outsourced domestic workers, reports:

It is not difficult to spot them from other children, wherever they are found. The privileged few among them attend public schools, with their uniforms patched in different places and most times, barefooted. If they manage to put on footwears (sic), such, would be glaringly begging to be replaced. They are the first to wake up in their homes. Yet they go late to school because they have to finish piled up chores. Some of them are never with textbooks and when they return home, they never have time to do their homework, except at midnight night (sic), when other members of the family 
would be sleeping. This is because they have to continue from where they stopped with the household chores. For others who never had the privilege of going to school, they are stuck at home with unending chores as well as taking care of children of their busy bosses. They are treated as slaves: wearing rags, eating leftovers, or once a day. Even when they are given food, it is rationed and they are never allowed to eat when other members of the family are eating, as they are always the last to eat and when they are allowed to, they eat in the kitchen or at a corner of the house (Usman 2020, vanguardngr.com).

The foregoing narrative succinctly captures the typical life-style of a childhouse-maid, also called 'house-girl', and gives us a glimpse of the general life-style of a girl-child, who does domestic work in a typical African familial setting. Usman further explains that many of these female children are taken from their parents at early ages, when they have yet been tutored on the nitty-gritty of housekeeping. Often, they express joy over the news of being taken away from their low income families with the promise of a better life; only to end up as 'glorified slaves'.

Many daily newspapers have reported varying stories of inhumanity to house maids by women. Women who are supposed to be protecting these female children, are also inflicting harm on them, thereby infringing on their rights, contrary to the requirements in the international declarations on child-rights. According to Usman's report:

- on May, 20, 2017, in Lagos State, an eight-year-old girl was beaten to death by her pregnant mistress,

- a ten-year-old girl, Joy, was also beaten to death by her mistress on December 19, 2016 at 3am, in her apartment at Bolale Oduniyi street in Lagos State,

- another ten year-old-girl was attacked with hot iron by her mistress on March, 2018,

- a police-woman allegedly poured hot water on her fifteen-year-old maid, Chinyere Igwe, for using the wrong condiments for her soup,

- a six-year-old girl was thrown out of a moving car for making her mistress's' toddler cry,

- hot water was poured on a nine-year old-girl, by her mistress on Sunday December 27, 2017.

These cases were atrocities committed by women. However, Usman points out that child-maids or 'house-girls' also suffer different forms of sexual harassment, molestation and rape by males in the home, including their mistress's husbands. In some cases, mistresses have killed teenage maids on suspicion of having affairs with their spouses, some of whom were forced to become wives, 
when they become pregnant. We are not denying that there are cases where ODGL does not deteriorate into what has been described as 'crimes on women by women' (Abraham 2020). Nonetheless, being witnesses to similar cases ourselves, we contend that ODGL is a structural problem here in Nigeria.

Now let us turn to the second victimology-narrative; a teenage girl who stabbed her husband in order to preserve her virginity. When interrogated by the Police, in her defense she said:

I never knew that sex is a marital [sic]obligation. On that fateful night when he approached me for sex, I refused him because I have never been involved in it. I honestly thought he wanted to defile me. He later got angry and was trying to force himself on me with slaps and beating, then I picked up a knife to scare him away but he kept coming. I didn't know when I stabbed him with the knife in his chest (Agwam 2020, vanguardngr.com).

Hassan's case is complicated. First it is a case of forced marriage and childmarriage, practices that are condemned by most feminists. As to whether forceful sex on a supposedly married teenage-girl by her husband amounts to rape is a complex matter, especially because it happens within a cultural system where girlchild-marriage is not regarded as a vice.

A teenage girl of eighteen-years may be seen as an adult according to international documents and treaties on child rights. However, in many parts of Africa, most girls at this age are still in high school, have recently completed high school, or are about to enroll in college, and are still very much dependent on their parents or custodians. They are not yet regarded as adults until they are in their middle to late twenties. It is difficult, therefore, for girls of this age, especially educated ones, to see themselves as ready for marriage. Some of them may not even be sexually active, which is one of the main reasons why they are exploited in the name of child-marriage. Some of the educated teenage girls from the Northern part of Nigeria who were interviewed by one of the authors of this paper during a workshop on girl-child empowerment, said they will not rush into marriage at the age of eighteen, irrespective of what their traditions hold, and that they will resist force by all available means.

It is disheartening that whereas the feminist struggle from its inception has been for the liberation of women, yet, ironically, some women who are supposed to 
reciprocate the ideals of the feminist struggle in their respective families and marital homes, are found doing the opposite. What could be the reason for this? It can be argued that women who commit these atrocities, as well as the victims to which these atrocities are meted, suffer hermeneutical ignorance in some sense. For instance, the victims of ODGL in Usman's narrative lack the concepts or skills or know-how to make sense of their experiences. Obviously, one reason for this is that many of the victims in Usman's narrative, are less than twelve-years of age and are still too immature to intelligibly make sense of their experiences. The other reason is their lack of exposure to feminist liberatory education - a pedagogy of liberation founded on the principles for social change and transformation. In this regard, it could be said that there is a hermeneutical gap, as these victims do not contribute to the collective hermeneutical resource.

The availability of expressive and interpretive resources for sense-making is one issue, but how these resources are used and by whom is another issue (Medina $2017,43)$. So too is the willingness to use these resources or share knowledge of these resources with another who really needs them for sense-making. The women in Usman's victimology-narrative perpetuating domestic violence may have access to concepts on how to treat their maids with dignity, but they refuse to use them or share them with their victims. One who perceives a member of a marginalized group with a prejudiced identity may have epistemic access to some relevant feminist concepts by which he or she can make sense of his or her social experiences, but chooses neither to use nor communicate in accord with this access, because of their unwillingness to part with the prejudiced identity. In this respect, one hides relevant knowledge that could help the oppressed liberate themselves, or to make sense of their experiences. By so doing, one distorts the collective hermeneutical resource, and incapacitates those who are marginalized. This is because the collective hermeneutical resource is somewhat bereft of relevant concepts that would have been useful in sense-making. This is what we call 'hermeneutical obstruction'. Hermeneutical obstruction incapacitates or impoverishes the collective hermeneutical resource, and renders it bereft of adequate concepts for hermeneutical dialogue between the oppressor and the oppressed. This is most 
likely what explains a situation where a known feminist scholar or activist, who is very much abreast with what constitutes hermeneutical injustice, but who does not act accordingly. It will be difficult to convince an educated audience, such as a professional lawyer, an evangelist or a banker, is absolutely ignorant about the concept of child-abuse or child-molestation or child-rights, to the point that he or she will commit homicide in the name of punishing an erring child-maid. Indeed, the feminist commitment to the emancipation of women in Africa is low, compared to Europe and North America (Oluwagbemi-Jacob, Egbai \& Abakedi, 2018). This is due to a number of factors, which include, but are not restricted to, a strong resistance from a cultural system of religious conservationism or traditionalism, which remain rigidly committed to a prejudiced identity of the girl-child as a 'domestic working machine' that is capable of doing all kinds of domestic labour (including sexual abuse by bosses, mistresses' spouses and male-children of their bosses), not minding if their bodies can withstand these horrendous acts, or how they affect them psychologically.

In comparing Hassan's case with that of Wood's, as discussed by Fricker (2007), Wood lacked the needed feminist concept to make sense of her experience of sexual harassment, and although Hassan also lacked the feminist concept to make sense of what she was experiencing, she knew she had the right to remain undefiled, in the same way that Wood knew she had the right to say no to perceived sexual advances. Whereas Wood resisted such advances by withdrawing from the system in which she found herself, for Hassan, violence became an option. The question, therefore, is: will Hassan be convicted or executed for murder? Unlike Wood, Hassan lives in the Northern part of Nigeria, a cultural system where it is normal for marriage to be contracted for children by their parents, against their will. This is the situation in many instances of girl-child marriage. Hassan is torn between the lack of adequate feminist concepts, or skills, to make sense of her experience, and a society where the concepts of 'girl-child-abuse' and 'girl-child-marriage' is suppressed by culture and tradition. In other words, Hassan lives in a phallocentric society, where female children are perceived with a prejudiced identity, that is, as purchasable tools for men's carnal desires. 
Juxtaposing the narratives of Usman and Agwam, we can see that ODGL is evidence that the rights of the girl-child are infringed upon or denied, including their right to education and choice of career, to choose when to marry and to reproduce, and to grow to mature adults before making such choices. In other words, this system robs the girl-child of her right to remain a child because they make a child assume the responsibilities of adults, such as parenting, when they are still children. Unfortunately, unlike Hassan, most of the younger female children who are engaged in girl-child-marriage do not know they have these legal rights. Their oppressors, some of whom may be aware of these rights, but hide under the umbrella of tradition or religion to perpetuate this anomaly, prevent their victims from having knowledge of their rights as children, such as knowing that one who forces a girl-child into marriage commits a crime against her humanity. By so doing, those who chose to marry children, make their victims suffer a hermeneutical gap, by preventing them from contributing to the collective hermeneutical resource. By concealing the truth of the illegality and wickedness of girl-child-marriage from their 'baby-wives', they foster hermeneutical obstruction. Often, such 'baby-wives' cannot complain to local feminist agencies because they do not exist in their local communities; neither can they complain to local authorities within the system they find themselves, because it is a taboo to do so. Hence, in this regard, they suffer hermeneutical interference.

Hassan's experience is a case of a hermeneutical gap, since she lacks the relevant feminist concepts and skills to make sense of her experience of being excluded from contributing to what happens in her reproductive life. Her fury arises from her desperation or possible depression, due to child-marriage being institutionalized and defended by the political and religious structures of the system within which she lives. So, resisting an attempt of forced sex by a husband that she obviously rejects, will be interpreted as resisting her marital obligations, which is seen as a taboo in this culture. Not even Hassan's parents can publicly defend her, if the matter appears before the customary courts. This is the reason why killing her husband over his supposed customary right may not be condoned by the customary judiciary processes. The point we are trying to make here is that even if Hassan were 
to have the relevant concepts to make sense of her experiences of forced sexual advances, she will be deterred by hermeneutical interference, which, in this context is the normalcy of forced-marriage as well as the cultural taboo of denying her husband his customary right to sex.

There are many girls whose experiences have not surfaced in the public sphere. This paper cannot capture all these cases. Hassan's case allows us to argue that child-marriage or teenage-marriage is one of the worst forms of outsourced ODGL. First, it is outsourced because the girl-child is made to leave her parents' home to the home of her husband who can here be described as representing a system that oppresses the girl-child. The labour of the girl-child-wife is multidimensional. She can be subject to a wide-range of unpaid labour, e.g., housechores, running errands for her husband and his other adult wives, and forced reproductive roles.

\section{the harm in domestic girl-child labour as a form of hermeneutical injustice}

According to Fricker, HI leads to two kinds of harms: the primary and the secondary harms. Whereas primary harms, which she calls 'situated hermeneutical inequality', exclude the epistemic agent from knowledge production on grounds of structural identity prejudice, secondary harms are the consequences that result from such an exclusion (Fricker 2007, 162-163). Where one is unable to partake in contributing to the collective hermeneutical resource, one lacks the concepts to make sense of one's experiences in one's immediate world or what we may call one's ontological context. What this means is that the epistemic agent fails to understand the immediate situation, and in that respect, does not have epistemic confidence or suffers what Fricker calls "loss of epistemic confidence" (Fricker 2007, 163). Moreover, and most importantly, HI can prevent one from becoming what one wants to be or make one turn into what one did not want to be (Fricker 2007, 168). We concur with Fricker, and her arguments aptly describe the harm that ODGL poses to the victims of the victimology-narratives of Usman and Agwam. 
The philosopher John Locke had speculated that the human mind, at birth, is like a blank slate, upon which experience writes. ${ }^{8}$ Adopting Locke's psychology will mean that a girl-child under the age of ten or above, who is made to face the horrors associated with ODGL as reported in the previous section, will have unpleasant experiences written on her memory, which may have a major influence on who she turns out to be, or how she makes sense of life generally in the future. For instance, people who were able to build their self-esteem earlier in their lives, because of the love they enjoyed as children, are not easily compromised when they become adults (Keshky and Samak 2017). If people who were able to build their selfesteem earlier in their lives, because of the love they enjoyed as children, are not easily compromised; there is a high probability that victims of ODGL will grow up with a low self-esteem that may be difficult to completely overturn even as adults (Hänel 2020). This is a crucial recommendation for a future study.

ODGL excludes its victims from knowledge production, renders them unable to make sense of their situation, and it may have many other consequences such as making victims see themselves as hopeless, worthless or less fortunate, or as condemned to the identity of slaves. The result of ODGL can be that female children become what they do not intend to be or are unable to become who they want to be. For instance, many victims of ODGL run away from their mistress's home and survive by begging on the streets, or by engaging in illicit drugs, prostitution and other acts of delinquency. We have heard stories about maids who have poisoned their mistress or inflicted other harms due to maltreatment, as a way of ending their predicaments. Hassan's case, for instance, is one such case where HI led to violence, where a girl who never intended to be a murderer, turns out to be one, or so it seems.

Excluding children from decisions made about their lives constitutes $\mathrm{HI}$ because it is a harm done to them as decision-makers (Baumtrog 2018, 301). In the same way, we can say that giving out a girl-child as an outsourced domestic worker amounts to HI. A girl-child is not yet psychologically ready to really understand what outsourced domestic work or forced marriage is, and one need not simply take

\footnotetext{
8 This is a philosophical thesis that is relevant to childhood philosophy of education.
} 
a yes as consent. This amounts to exploiting the girl-child's immaturity and ignorance.

The victimology-narratives are compatible with Hänel's thesis that $\mathrm{HI}$ is simply a problem of misrecognition (Hänel 2020, 343). We think this view is explicated in the cases narrated by Usman and Agwam. Victims of ODGL, who are perceived from a prejudiced identity, are misrecognized as human domestic work machines, who must work even when tired, weak or sick, or as baby-making machines who must become mothers even when not biologically or psychologically prepared. What best describes this is slavery. In these contexts, the real identity of the victim, as a child of a fellow-woman, is somewhat suppressed and replaced by a false identity, which allows for incessant abuses and marginalization. Hänel argues that misrecognition is grounded in the absence of love, respect and esteem, which leads to the denial of rights and exclusion, denigration and insults, as well as physical abuse, torture and possibly rape (Hänel 2020, 341-2). By application of Hänel's argument, we can say this is true about ODGL. Misrecognition erodes the girl-child's self-respect, self-esteem and self-confidence. It threatens her social and physical integrity, honour and dignity. There is a need to intensify efforts in checkmating different forms of epistemic injustice done to children as human beings. In the following section, certain measures to combat ODGL are given

\section{combating outsourced domestic girl-child labour}

Outsourced ODGL is not only a form of HI, but a form of social injustice to girl-children from low-income backgrounds. In making proposals for combating HI in the recent literature, there is what seems like a commitment to a metaphysics of essentialism, i.e., the tendency to anchor feminist resistance of sexism, androcentricism and phallocentricism on the presupposition of the equality of males and females. From the time of first, second and third wave feminism, the dominant dimension has been to argue for equal opportunities for both men and women on grounds that both have the same essence or the same human dignity (Oluwagbemi-Jacob, Egbai \& Abakedi 2018). Understandably, sameness of essence or oneness of nature, was used to radicalize prejudiced definitions and 
misrecognition of women at the time, such as the type seen in Aristotle's Politics, presented men as having a deliberative faculty that women do not have in the same degree. The argument that both sexes have the same essence was a good approach to debunk Aristotle's anti-feminist stance (Oluwagbemi-Jacob, Egbai \& Abakedi 2018). However, one advantage of anchoring feminism in the metaphysics of essentialism is that it allows for the possibility of discussing the equality of men and women as being entitled to the same natural and civil rights (Oluwagbemi-Jacob, Egbai \& Abakedi 2018).

Even in international treaties and documents on child-rights, the language is general, and the concern is about equal rights for both sexes of children, as can be seen in the African Charter on Human and People's Rights [art. 18[3]); the African Charter on the Rights and Welfare of the Child; the American Convention on Human Rights (art.19); the American Declaration of the Rights and Duties of Man (art.7); the Convention on the Elimination of All Forms of Discrimination against Women (arts. 10 and 16); the Convention on the Protection of the Rights of Migrant Workers and Members of their Families (arts. 29-30, 45); the International Labour Organization's Document on Worst Forms of Child Labour Convention 1999; and the United Nations Convention on the Rights of the Child' (IJRC 2020). The Convention on the Rights of the Child (CRC), in article 32, declares that the child has the right to be protected from economic exploitation, interference in their education, or harms to their health or physical, mental, spiritual, moral or social development (UNICEF 2007).This document declares, for example, that children should participate in decisions affecting them; that they should be protected against discrimination, neglect and exploitation; that provision for children's basic needs should be made compulsory; that children have the right to freedom from sexual exploitation; and that they have the right to freedom from child labour (IJRC 2020). With all these in place, the incidences in the narrative of Usman concerning ODGL are simply unjustifiable and punishable by international law.

It is pertinent to ask whether these treaties are the product of the harmonization of the 'voice of the child', or they are merely the voices of adults for children. This is one of the issues discussed in philosophy for children (P4C). The 
literature on P4C (cf. Elicor 2020; Kohan 2014; Murris 2013; Kennedy \& Kohan 2017; Sandoval \& Sykes 2017; Nichols, Burgh, \& Fynes-Clinton 2017; Glaser \& Gregory 2017; Haynes \& Murris 2017; Gasparatou 2017; Chetty \& Suissa 2017) is vast and addresses a diverse range of educational issues, but generally it focuses on "bringing philosophy to school classrooms and other learning contexts, and bringing children's voices into moral and political arenas and to philosophy" (Gregory, Haynes \& Murris 2017, xxi). In this paper, we propose that in order to create awareness in children about relevant hermeneutical interpretive resources, educational curricula at all levels should be revised to include such interpretive resources. But this will mean bringing hermeneutical interpretive resources to the classrooms. In this regard, this paper preserves the tradition of $\mathrm{P} 4 \mathrm{C}$.

We propose that since the victims of ODGL in the victimology-reports are mostly females, hermeneutical resources that can help female children make sense of their experiences must be brought to the classrooms. This will equip the girls with the needed concepts for sense-making, and the knowledge of such concepts by the males could help them form positive characters towards women when they become adults.

We propose that in combating ODGL, the 'voice of the girl-child', that is, the testimonies of victims who are female children, should be given utmost priority. This is necessary because there is a gap between the testimony of the child and legal practice (Birnbaum \& Saini 2012), and in many instances, children's testimony are often rejected or discredited because they are not given the same value as the testimonies of adults (Baumtrog 2018, 298). This is a form of testimonial injustice, and, thus, fixing this gap is important because in some cases, a child may be the only witness to a crime (Baumtrog 2018, 298).

In applying the principles spelt out in international treaties and documents on child-rights to different cases of violations, the testimonies of the girl-child should not just be treated as less-reliable evidence, otherwise this will amount to testimonial injustice. In Hassan's case, we argue that Hassan's action should be seen as an action of self-defense against a dehumanizing practice. Hassan's forced or arranged marriage to her husband is already a case of infringement on her rights, 
as spelt out in article 32 of the CRC. And forced sex will also amount to a further harm to Hassan, since her virginity is of value to her and she sees the need to preserve it, as one preserves one's life. The reason is simple, defiling her will mean introducing into her world such things as emotional and psychological trauma, coupled with nuptial and maternal responsibilities she is unprepared for. It will further attract an unwanted prejudiced identity, such as 'teenage-mother' or 'school drop-out'.

Taking the 'voice of the girl-child' into consideration has a way of announcing her difference as a biological person, a psychological person, a moral person and as a social person. We note that the language in the different declarations on child-rights addresses children generally but does not highlight the right of the girl-child specifically to underscore her difference. For instance, fixing fifteen as the minimum age for child-labour, by the International Labour Organization (ILO), may not augur well for the girl-child in some parts of the world. This declaration presumes that at the age of fifteen, every girl-child is psychologically and biologically fit to engage in paid labour. But this is not necessarily the case. In West Africa, many female children at this age are still unable to come to terms with their biology as females, and are not able to properly manage the psychological specificities that come with this. We think that if the differences of the girl-child, with respect to biology, race, culture, region and economy were adequately considered before drafting this document, and if the testimonies of especially female-children in Sub-Saharan Africa, were adequately considered, there will be no need to stipulate any age limit, without clearly specifying what specific nature of job the girl-child should do at this age. If this document can be interpreted as permitting fifteen-year-old children to engage in paid domestic labour, there are obviously no clear rules on how this should be controlled.

The prevalence of different acts, treaties and international documents on child-rights, and the seeming incessant violation of these rights by persons in their respective local communities, calls for serious reflection. It makes us ask whether there is sufficient publicity about different declarations on child-rights. If not, why? The declarations on child-rights contain relevant concepts, by which children who 
suffer the experiences mentioned in both victimology-narratives can make sense of their experiences either by way of resistance or by appealing to relevant international agencies, through legal means. But this can only happen in a system that prioritizes the defense of children against all manners of abuse. A system that institutionalizes ODGL or child-marriage, can hardly domesticate the declarations of the CRC on child-rights. In other words, a system that defends ODGL can hardly enact laws that prohibit it. To do that, such a system must be ready to radicalize the false identity or misrecognition given to the girl-child. But it appears that the cultural system, within which Hassan lives is not yet ready for this.

We argue here that if there are relevant feminist agencies within such a system, which are supported by international bodies such as the AU or the UN, local authorities could be compelled to consider feminized legislations that will render such practices illegal. This will be a bold step in the right direction. However, such agencies should be able to guarantee the confidentiality of reported cases as well as the protection of victims whose cases are reported and help such victims to get legal justice. Furthermore, there is urgent need to render the declarations on child-rights intelligible in such a manner that children can get familiar with them, from the outset of basic education through their secondary and tertiary education. This calls for a radical reconstruction of existing educational curricula in all the countries of the world, especially in countries in Sub-Saharan Africa because ODGL is more frequent where there is a widespread of poverty. There is also a need for curriculum developers and experts to liaise with policy makers in different countries to ensure that declarations on child-rights are simplified and adequately accommodated within syllabuses of subjects at all levels of education. This will also be an opportunity to accommodate relevant feminist concepts such as sexual harassment, sexual molestation and rape within the educational curricula. This is one way of combating the hermeneutical gap. It will go a long way to eradicate hermeneutical interferences that surface as different societal taboos that help in the institutionalization of ODGL.

In many countries of the world, international declarations on child rights are not taught to children at the level of basic or post-basic education. There is no 
guarantee that this is done at the tertiary level, except in rare cases where the contexts of discussions are about history. We think feminist liberal education is relevant for the fight against ODGL because it equips one with the relevant concepts needed to make sense of different experiences of oppression. Education is the surest way to create awareness about different forms of child abuse in the younger generation. This can be done by exposing them at very early ages to what they need to know about child rights. When this is done, they will grow up with the knowledge of the relevant interpretive hermeneutical resources that will help them make sense of their experiences. This is why we think there is a need to revise the educational curricula to include topics like the international declarations on childrights, child abuse, child molestation, child labour, domestic violence and rape, so that children will have access to them from very early ages, and use them as interpretive resources whenever they need arise. ${ }^{9}$

In addition to revising the educational curricula, social groups supervised by feminist instructors should be established in places such as schools, churches, villages, communities, hospitals and health centers to guarantee the propagation of feminist liberation education. Feminist liberation education should be promoted with motion-arts and in social media outlets such as Facebook, Twitter, and WhatsApp. This should be accompanied with a rigorous campaign for the enforcement of the international declaration of child rights, as well as a more proactive approach to bringing violators of such rights to justice.

Finally, we encourage the formation of feminist political parties, and members of such parties should vie for political offices concerned with policymaking and decision-making. Putting an end to ODGL also requires legislation, and without adequate representation in the upper and lower chambers of legislative processes, this may not be feasible. We see nothing wrong, therefore, in encouraging women to vote for women aspirants, to ensure victory for the feminist cause. One way of doing this is to give women good reasons to do so. For

\footnotetext{
${ }^{9}$ We acknowledge the contributions of the second anonymous reviewer concerning the need to clarify why feminist liberal education is recommended in this paper. However, we do not think we have to devote a whole section to that purpose, since feminist liberal education is not recommended as a replacement for existing curricula, but rather as a theoretical model that can allow for the kind of curriculum-revision we are proposing.
} 
instance, those vying for political offices must be sincere about tackling the plights of women and girls, and all kinds of injustices against females in their campaign manifestos.

\section{conclusion}

In this paper, we explored HI from the perspective of the hermeneutical gap, hermeneutical dissent and hermeneutical interference. Using two victimologynarratives, we highlighted some horrible experiences that victims of ODGL face, and argued that ODGL is a form of HI because it explicates the hermeneutical gap, hermeneutical interference, as well as hermeneutical obstruction. We argued that adding the 'voice of the girl-child' during decision-making-processes involving female children should be prioritized, as a way of underscoring her difference which is mostly suppressed by addressing children matters generally. We have pointed out that this is necessary in policymaking and legislation, if the war against ODGL as a form of HI must be won by feminists. We have also argued that there is a need for the radicalization of social structures that perpetuate ODGL, as well as educational curricula to accommodate the 'voice of the girl-child' ${ }^{10}$ We have also argued that feminist liberal education could be further fostered by the introduction of feminist agencies in different social institutions. By so doing, children and adults will come to the awareness of basic relevant feminist concepts needed for postmodern understanding of social justice.

\section{acknowledgements}

We acknowledge the contributions of faculty members and postgraduate students during the development of this manuscript. We also acknowledge the contributions of two anonymous reviewers.

\footnotetext{
${ }^{10}$ Just as different contexts give rise to different logics (Abakedi 2020), the uniqueness of contexts of the voices of female children should be taken into consideration when making general policies for children.
} 
hermeneutical injustice and outsourced domestic girl-child labour

\section{references}

Abakedi, D. E. (2020). A critique of metaphysical logical realism. Meta: Research in Hermeneutics, Phenomenology, and Practical Philosophy, 12 (1), 127-142.

Abraham, O. (2020). Maid brutality in Nigeria: Crimes on women by women. Retrieved from Vanguard, http://www.vanguardngr.com/2020/07/crimes-on-women-bywomen.

Agra, K. L. R. P. (2020). Epistemic injustice, epistemic paralysis and epistemic resistance: A feminist liberatory approach to epistemology. Kritike, 14 (1), 28-44.

Agwam, C. (2020). Teenage wife kills husband over sex, says she didn't know its' marital obligation. Retrieved from Vanguard, http://www.vanguardngr.com/2020/05/teenage-wife-kills-husband-says-shedidn't-know-its-marital-obligation.

Baumtrog, M. D. (2018). Navigating a necessary inequality: Children and knowledge-based injustice. Alternate Routes: A Journal of Critical Social Research, 29, http://www.alternateroutes.ca/index.php/ar/article/view/22459.

Begum, R. (2016). Migrant domestic workers: Overworked and underprotected. Women Across frontiers (4) http://wafmag.org/201/migrant-domestic-workersoverworked-underprotected.

Birnbaum, R., \& Saini, M. (2012). A qualitative synthesis of children's participation in custody disputes. Research on Social Work Practice, 22 (4), 400-409.

Chetty, D., \& Suissa, J. (2017). No go areas: Racism and discomfort in the community of inquiry. In M. R. Gregory, J. Haynes, \& K. Murris (Eds.), The Routledge International Handbook for Philosophy and Children (pp.11-18). London and New York: Routledge.

Congdon, M. (2017). What's wrong with epistemic injustice? Harm, vice, objectification and misrecognition. In M. Congdon, \& I. James and J. Kidd (Eds.), The Routledge Handbook of Epistemic Injustice. New York: Routledge.

Crerar, C. (2016). Taboo, hermeneutical injustice, and expressively free environments. Episteme, 13 (2), 195-207.

Dotson, K. (2011). Tracking epistemic violence: Tracking practices of silencing. Hypatia: A Feminist Journal of Philosophy, 26 (2), 236-257.

Elicor, P. P. E. (2020). "Mapping identity prejudice: Locations of epistemic injustice in philosophy for/with children", Childhood \& Philosophy, 16 (1), 1-25.

Elzinga, B. (2018). Hermeneutical injustice and liberation education. The Southern Journal of Philosophy, 56 (1), 59-82.

Fricker, M. (2007). Epistemic injustice: Power and the ethics of knowing. Oxford: Oxford University Press.

Fricker, M. (2016). Epistemic injustice and the preservation of ignorance. In R. Peels \& M. Blaauw (Eds.), The dimensions of ignorance (pp. 160-177), Cambridge: Cambridge University Press.

Gasparatou, R. (2017). Philosophy for/with Children and the development of epistemically virtuous agents. In M. R. Gregory, J. Haynes, \& K. Murris (Eds.), The Routledge International Handbook for Philosophy and Children (pp. 103-110). London and New York: Routledge.

Giladi, P. (2018). Epistemic Injustice: A role for recognition. Philosophy and Social Criticism, 44 (2), 141-158.

Glaser, J., \& Gregory, M. R. (2017). Education, identity construction and cultural renewal: The case of philosophical inquiry with Jewish Bible. In M. R. Gregory, J. Haynes, \& K. Murris (Eds.), The Routledge International Handbook for Philosophy and Children (pp. 180-188). London and New York: Routledge.

Goetze, T. (2018). Hermeneutical dissent and the species of hermeneutical injustice. Hypatia: A feminist Journal of Philosophy, 33 (1), 73-90. 
Haynes, J. \& Murris, K. (2017). Readings and readers of texts in philosophy for children. In M. R. Gregory, J. Haynes, \& K. Murris (Eds.), The Routledge International Handbook for Philosophy and Children (pp.171-179). London and New York: Routledge.

Hull, G, (2017). Black consciousness as overcoming hermeneutical injustice. Journal of Applied Philosophy, (34) 4, 573-592.

International Justice Resource Center (IJRC). (2020). Child rights. Accessed July 20, 2020, http://ijrcenter,org/thematic-research-guides/childrens-rights.

International Labour Organization (2013). World Report on child labour: Economic vulnerability, social protection and the fight against child labour. Geneva: International Labour Organization.

International Labour Organization (2020). What is child labour. Accessed July 17, 2020. http://www.ilo.org/ipec/faacts/lang.

Kennedy, D., \& Kohan, W. O. (2017). Childhood, education and philosophy: A matter of time. In M. R. Gregory, J. Haynes, \& K. Murris (Eds.), The Routledge International Handbook for Philosophy and Children (pp. 46-52). London and New York: Routledge.

Keshky, M. E., \& Samak, Y. A. A. (2017). The development of self-esteem in children: Systematic review and meta-analysis. International Journal of Psychology and Behaviour Analysis, 3, 128.

Kohan, W. (2014). Philosophy and childhood. New York: Palgrave.

Kidd, I., Jose, M. \& Pohlhaus, G., Eds. (2017). The Routledge handbook of epistemic injustice. New York: Routledge.

Maitra, I. (2018). New words for old wrongs. Episteme, 15 (3), 345-362.

Medina, J. (2017). Varieties of hermeneutical injustice. In I. J, Kidd, J. Medina, \& J. G. Pohlhaus (Eds.), The Routledge Handbook of Epistemic Injustice (pp. 41-52). New York: Routledge.

Moors, A. (2003). Migrant domestic workers : Debating transnationalism, identity politics, and family relations, a review essay. Comparative Studies in Society and History, 45(2), 386-394.

Murris, K. (2013). The epistemic challenge of hearing child's voice. Studies in Philosophy and Education, 32 (3), 245-259.

Nichols, K., Burgh, G. \& Fynes-Clinton, L. (2017). Reconstruction of thinking across curriculum through the community of inquiry. In M. R. Gregory, J. Haynes, \& K. Murris (Eds.), The Routledge International Handbook for Philosophy and Children (pp. 245-252). London and New York: Routledge.

Oluwagbemi-Jacob, Egbai, M. J., \& Abakedi, D. E. (2018). A General Introduction to Feminist Philosophy: Studies in Feminist Philosophy http://www.amazon.com/Generalintroduction-Feminist-Philosoph-PhilPhuilosophy/dp/1726434966.

Podolsky, P. (2018). Hermeneutical injustice and animal ethics. Can non-human animals suffer from hermeneutical injustice? Journal of Animal Ethics, 8 (2), http://doi.org/10.5406/janimalethics.8.2.0216.

Reed-Sandoval, A., \& Sykes, A. C. (2017). Who talks? Who listens? Taking 'positionality' seriously in philosophy for children. In M. R. Gregory, J. Haynes, \& K. Murris (Eds.), The Routledge International Handbook for Philosophy and Children (pp.219-226). London and New York: Routledge.

Richer, P. \& de Coninck, S. (2015). Responsible finance and child labour: Quo vadis microfinance? Enterprise Development and Microfinance, 26 (2), 158-174.

Shahvisi, A. (forthcoming). Hermeneutical injustice and outsourced domestic work. Women's Studies International.

Tundui, C. S., \& Tundui, H. P. (2018). Examining the effect of child labour in the profitability of women owned enterprises: a case of microcredit supported enterprises in 
hermeneutical injustice and outsourced domestic girl-child labour

Tanzania. Journal of Global Entrepreneurship Research, 8 (2), http://doi.org/10.1186/540497-018-0088-4.

United Nations Children Fund (UNICEF) (2020). Legislative reform on child domestic labour: A gender analysis. United Nations Children Fund (UNICEF).

Usman, E. (2020). Maids as glorified slaves in in Nigeria. Retrieved from Vanguard: http://www.vanguardngr.com/2020/02/ maids-as-glorified-slaves-in-nigeria.

received in: 27.07.2019

approved in: 15.10 .2019 